\begin{abstract}
Charles Dickens is not usually remembered as a dramatist; in fact, the contemporary success of his subsequently neglected dramatic writing is predicated on the absence of the authorial persona that we now consider 'Dickensian'. Drawing on findings from a practice-led research project, which staged Dickens's burletta Is She His Wife? or, Something Singular!, this article examines what performing this play can tell us about Dickensian dramaturgy and nineteenth-century theatrical culture. Interrogating the role of practice-led research in the study of nineteenth-century drama, we suggest that this methodology allows contemporary scholars to look beyond Dickens's contemporary significance as a canonised literary and heritage figure. Our historically informed production illuminates the ways in which Dickens used material properties, music, and performance strategies to stage-manage his own disappearing act as a playwright.
\end{abstract}

\title{
Keywords
}

Dickens; burletta; practice-led research; scenery; rehearsal; 1830s 


\section{Is He a Dramatist? Or, Something Singular! Staging Dickensian Drama as Practice-Led Research}

(Enter a Servant.)

Servant.-If you please, sir, here's a person wants to speak to you.

Manager.-I'm busy about the opening of the theatre; tell him you can't get near me.

Servant.-But he says he's an author, sir, and has called about his piece.

Manager.-His piece! why, these authors let me have no peace at all.

Servant.- - He would come up, sir, though I told him you wouldn't suffer any one behind the scenes.

Manager.-And particularly an author; for he makes people suffer enough before them. ${ }^{1}$

For contemporary audiences, it is impossible to detach Charles Dickens's cultural status from our reception of his dramatic works. He looms large in the heritage industry, and his life and novels continue to be the subject of countless monographs, adaptations, and other creative remediations, such as the recent Our Mutual Friend Twitter Project. ${ }^{2}$ It might be surprising, then, that the parodic skit above, in which the author plays upon his own unimportance, was written by Dickens concurrently with the 1836-7 theatrical season in which three of his plays were performed at the St James's Theatre: The Strange Gentleman, The Village Coquettes, and the farcical burletta Is She His Wife? or, Something Singular! Dickens's letters from the period preceding the first professional production of The Strange Gentleman suggest that his experiences did not resemble his fictional author's struggle; Dickens was not excluded backstage, but 'superintend[ed] its preparation, morning, noon, and night', with a level of involvement characteristic of his efforts to retain control over multimedia representations of his better-known works. ${ }^{3}$ Yet in responses to our research production of Is She His Wife?, audience members repeatedly commented that Dickens's dramatic writing was 'surprising', drawing contrasts between Dickens's modern legacy and this little-known dramatic work, and stressing the absence of Dickens's authorial persona (see appendix). Far from seeking to effect a controlling authorial presence, in writing for the stage, Dickens stage-manages his own disappearing act, and it is this, we argue, that makes him a successful dramatist. Although we 
chose to stage this particular play because of its Dickensian genesis, our practice-led method revealed that we were looking for the author in a genre that demands his or her absence.

In this article we ask what staging Is She His Wife? can tell us about Dickensian dramaturgy, and interrogate the role of practice-led research in the study of nineteenth-century drama. We do not make a case that Dickens should be recognised as an important dramatist, but, rather, suggest that insights gathered from practice-led research open up rich lines of enquiry, in relation to both Dickens's dramatic works, and nineteenth-century theatrical cultures more widely. We explore how our production illuminates the generic, dramaturgical, musical, and theatrical characteristics of Is She His Wife? as an example of a burletta, and argue that the interactions between the text, the music, and the set at once enabled us to test the performability of the play, and facilitated the removal of Dickens himself.

Is She His Wife? is very much a domestic affair. It revolves around the troubled marriages of two country-dwelling couples: the Lovetowns and the Limburys. Piqued by her husband's neglect, Mrs Lovetown flirts with neighbouring bachelor Felix Tapkins in order to rouse Mr Lovetown's jealousy. The titular, farcical confusion ensues when Tapkins mistakes Mrs Lovetown's meaning, inferring a clandestine relationship with Mr Lovetown, and that she is in fact married to someone else. Angered by their flirtation, Mr Lovetown plans to entrap his wife by feigning unawareness of her actions. Deciding to 'pay particular attention' to Mrs Limbury instead, he aims to 'lull [his] wife and that scoundrel Tapkins into a false security, and have better opportunities of observation. ${ }^{4}$ Despite the play's domesticity, it has racy overtones, generating humour by implying adultery and bigamy - another factor that some of our audience found surprising, given the 'moralising' tone they associated with Dickens's novels.

First performed on 3 March 1837, Is She His Wife? ran for two months; following Dickens's two earlier contributions to the St James's programme, it ensured that his dramatic 
works were 'on the boards of the theatre for much of the season.' ${ }^{5}$ Is She His Wife? fared respectably, given that it premiered late in the season, particularly when compared to an anonymous early adaptation of Oliver Twist staged at the St James's a year later, which was a decided failure and only lasted one night. ${ }^{6}$

In staging Is She His Wife?, we aimed to take Dickens's play seriously as a reasonably successful farce, exploring the benefits of performing, rather than simply reading, Dickens's plays, and raising public awareness of Dickens's more obscure works. Our motives for choosing this particular play were also practical: Is She His Wife? is short, with a run-time of around forty minutes, has a small cast, and does not demand extravagant scenery. We staged two performances of the play. The first was a public performance at King's College London, and the second followed an academic symposium at the Charles Dickens Museum. A recording of the first performance is available online. ${ }^{7}$

We use the term 'practice-led' to describe our methodology: 'practice' rather than 'performance' because our project incorporated an examination and construction of the material conditions of staging a play, as well as of acting and performing the music; and 'practice-led' because we used the process of staging Dickens's play as a mode of exploration, rather than as a means of testing a pre-existing hypothesis. ${ }^{8}$ Research in both digital and manuscript archives (including the Lord Chamberlain's Collection at the British Library, the Theatre and Performance Archive at the V\&A, and online databases) was conducted in preparation for the play, and continuously alongside its development. Building scenery, sourcing and composing music, and working with actors on performance techniques, has developed our interpretation of the text, and has enabled us to draw conclusions about the benefits and pitfalls of our methodology.

As Marvin Carlson puts it: 
Theorizing a cultural phenomenon involves selecting [from] among a wide variety of possible critical strategies, with the awareness that each approach may potentially reveal important aspects of the phenomenon but that none can provide anything like a total understanding. ${ }^{9}$

In our interdisciplinary approach, we use a range of critical and theatrical strategies to interrogate our own production choices, and to explore what this might illuminate about the text itself, mid-nineteenth-century conditions of rehearsal and performance, and the implications of staging an amateur production of a little-known Dickens play today. The collaborative manner in which the play evolved meant that there was a continual process of questioning during development, and that the final production was the result of an extended conversation. The interplay of performative, material, and cultural factors which influenced our interpretation, and which were discussed by various voices (the production team, the actors, and external academic advisors) echoes Jacky Bratton's concept of 'intertheatricality', a defining factor in nineteenth-century theatrical cultures. ${ }^{10}$

One methodological problem we explored was the concept of a historically informed production. Just as historical fiction tends to reflect the moment of its production more than the past it purports to represent, how might we measure the degree to which we succeeded in creating a historically informed play? Did our desire to recall aesthetics of a nineteenth-century theatrical experience ultimately counteract the innovations we hoped to make by employing a practice-led methodology? Would our play appear to fetishize the past in a retroactive manner, rather than offer opportunities for sensory engagement with a little-performed work? This article interrogates our decisions in creating a historically informed set; using shared lighting; rehearsing using nineteenth-century rehearsal and performance practices - including actors' parts (the short cues and lines that each actor received in lieu of the entire script), a limited rehearsal period, and an offstage prompter; and both using and composing period-appropriate music. 
We gathered actor experiences and audience responses in formal questionnaires, and by recording informal observations during a post-performance $\mathrm{Q}$ and $\mathrm{A}$. In so doing, we followed the model proposed by Stephen Purcell, collecting 'raw and immediate' responses to open-ended, qualitative questions. ${ }^{11} \mathrm{We}$ do not attempt to map contemporary audience responses onto a nineteenth-century audience, but rather to use actor experiences, audience responses, and analysis of our involvement as director, producer/set-designer, and musical director, to effect a theatrical close reading of the play in performance.

Performance is necessarily ephemeral, yet our practice is perhaps no less transitory and ambiguous than archival research. Diana Taylor argues that the distinction 'between the archive of supposedly enduring materials (i.e. texts, documents, buildings, bones)' and 'the socalled ephemeral repertoire of embodied practice/knowledge (i.e. spoken language, dance, sports, ritual)' may be more permeable than has previously been supposed. ${ }^{12}$ Archive-led studies mine and analyse sources in order to assess what elements might be extracted and redeployed within a (historical) narrative, or to influence literary criticism, in a similar way to practice-led research. As Walter Benjamin argues, the archive is itself ephemeral; far from a repository of 'fact', it is an unstable, unfixed construct, influenced by the choices of a collector. A historically-informed production, while analogously a constructed mode, offers audiences the opportunity for sensory engagement with an obscure work, and, embodied in performance rather than visualised from reading the text, reveals aspects of actor-audience dynamics, gesture and movement, musical and material interactions with the text, and Dickensian dramaturgy.

\section{Performing Is She His Wife: Cues, Character, and the Actor-Audience Dynamic}

In On and Off the Stage, Jerome K. Jerome recounts his experiences as an actor upon first receiving his 'part': 
Hurriedly I unfolded the paper, to see what kind of a part I had got. I was anxious to begin studying it immediately. I had to form my conception of the character, learn the words and business, and get up gesture and expression all in one week. ${ }^{13}$

The paper includes his lines, and two or three word 'cues'. This was the standard model of line learning in the period; no actor (whether a bit-part performer or the star) expected to see the entire script. The whole was under the control of the prompter, who not only 'copied lines and cues for each performer' but also 'heard actors rehearse them'. ${ }^{14}$ This 'rehearsal' comprised the majority of an actor's preparation for a part; group rehearsals were few, and more focused upon the mechanics of the production than individual actor choices. The full text was rarely rehearsed, but instead, 'the last two or three words, forming the cues, were clearly spoken, but the rest was... mumbled through, skipped altogether, or else represented by a droning 'er, er, er,' interspersed with occasional disjointed phrases'. ${ }^{15}$

In staging Is She His Wife? we used historically-informed rehearsal methods to interrogate Dickens's use of these theatrical conventions: actors learned their lines from parts, rather than from the full script; the rehearsal period was short; and we had limited group rehearsals. As director, Emma Whipday avoided giving what would be understood today as 'direction', and instead inhabited the role of the nineteenth-century 'prompter', working on actors' parts in rehearsal, and sitting offstage ready to prompt during the performance. However, we also maintained an awareness that the actors (a mixture of professionals and volunteers) had been trained in a modern theatrical tradition. We used anachronistic theatrical tools - from warm-up exercises to discussions of 'character' - to assist our twenty-first-century actors in preparing their nineteenth-century 'parts'. In our rehearsal, we focused upon three key theatrical conventions: a presentational acting style; the actor-audience relationship, facilitated by asides and direct address to the audience; and the use of actors' parts. 
Just as in analysing his novels we remember that they were written first for serialisation, so we need to consider that Dickens - who himself once dreamed of acting - would have been aware that for actors, the play existed in 'parts'. Simon Palfrey and Tiffany Stern's Shakespeare in Parts highlights the extent to which Shakespeare, attuned as an actor and shareholder to the processes of performance, embeds instructions to actors within the parts themselves, using cues to prompt particular reactions in an actor which would, in turn, illuminate something about the reactions of the character: for,

in drawing us closer to the processes of theatrical production - logistical, material, and phenomenological - thinking about parts can cast intimate and even secret light upon writerly design'. ${ }^{16}$

Such 'design' is not exclusive to Shakespeare, but there has been, to our knowledge, no similar close reading of the use of parts by Dickens, or in nineteenth-century theatre more broadly. ${ }^{17}$ While it is not necessary to perform with parts to analyse a writer's use of this, practical research experiments can draw attention to how these parts function in performance. ${ }^{18}$

Rehearsing and performing with parts was a new experience for the majority of our actors, and often a daunting one. Cue phrases, only two or three syllables long, give almost no information about the lines of other characters, forcing the actors to listen carefully as they waited for their cues. Andy Murton (Mr Lovetown) observed that this was 'problematic', but also beneficial:

I'm frustrated when watching actors on stage who don't appear to be LISTENING. Cue scripts require the actor to listen!

In rehearsing our production, we were alert to one particular kind of instruction that a playwright can embed in actors' parts: repeated, or 'false', cues. These can force an actor to 
speak 'early', and to seem to interrupt another actor, which can give actors a short cut to developing a sense of character, or character relationships. ${ }^{19}$

Repeated cues seem to be a tool that Dickens uses throughout Is She His Wife? In the first half of Is She His Wife?, these repeated cues are used to signal conviviality, to give information about a character or relationship, and to create a moment of hilarity. The former two functions are evident in Tapkins's first conversation with the Lovetowns:

Mrs. L. Ha, ha, ha! I'm afraid you're a very bad man, Mr. Tapkins; I'm afraid you're a shocking man, Mr. Tapkins.

Tap. Think so? No, I don't know; not worse than other people similarly situated bachelors, my dear Mrs. Lovetown, bachelors - eh, old fellow. (Winking to Lovetown.)

Love. Certainly, certainly.

Tap. We know - eh! (They all laugh.) (4)

What we may assume to be Tapkins's first cue - 'Mr Tapkins' - is repeated twice; in Tapkins's cue-script, it would look something like this:

\section{Mr Tapkins.}

Think so? No, I don't know; not worse than other people similarly situated bachelors, my dear Mrs. Lovetown, bachelors - eh, old fellow. (Winking to Lovetown.) certainly.

Tap. We know - eh!

This prompts Tapkins to speak early, so that his humorous reply overlaps with Mrs Lovetown's second statement, giving a sense of Tapkins's dominance of the situation. The same is true of Tapkins's next cue, where Lovetown repeats the cue word - 'certainly' - twice, again prompting Tapkins to interrupt. Tapkins's cue-words here at once establish the intimacy he shares with the Lovetowns, and give a sense of his character. 
Repeated cues can also interact with physical comedy, as when Mr Lovetown attempts to make his wife jealous by flirting with Mrs Limbury:

Love. Sit down - sit down! (Lovetown places the chairs so as to sit between them, which Limbury in vain endeavours to prevent.)

Mrs. Lim. Peter and I called as we passed in our little pony-chaise to inquire whether we should have the pleasure of seeing you at Tapkins' this afternoon. (5)

Mrs Limbury's imposing personality (and disregard for social niceties) is signalled by her willingness to interrupt her host before his second 'sit down' (her cue word), and also intersects with the moment that Lovetown forces her husband out of the seat next to her - a moment that generated much audience laughter in our stagings. A few lines later, another false cue prompts her to interrupt her husband, giving us a sense of their marital dynamics:

Lim. Fears that we mightn't be there! Of course we shall be there.

Mrs. Lim. Now don't talk, Peter. (5)

Mr Limbury is both figuratively and literally silenced by his wife, as her cue words - 'be there' - prompt her to talk over his reply even as she tells him not to talk. Even if the prompter has transcribed three words as the cue ('shall be there'), the similarity of the cue-words and the earlier phrase has the potential to alert the actress playing Mrs Limbury to the possibility of such an interruption.

In the comic climax of the exchange, when Mr Limbury is summoned by the servant to deal with a disobedient bay pony, his own words and wishes are again ignored:

Mrs. Lim. Oh! he'll kick somebody's brains out, if Peter don't go to him!

Lim. But perhaps he'll kick my brains out if I do go to him! 
Love. Never mind; don't lose an instant - not a moment! (6)

The use of Mr Lovetown's cue words ('go to him') at the end of both Mrs Limbury and Mr Limbury's lines, all but ensure that Lovetown will speak over Limbury, even as he forces him from the room.

In the second half of the play, the frequency of repeated cues dramatically decreases; the escalating action, large number of asides, and the recurrent device of hidden characters commenting on the action to the audience, would make any dropped or confused cues highly problematic. However, a couple of repeated cues do occur, in both cases in heated exchanges between Lovetown and Tapkins, where the cue-phrase is repeated twice, for emphasis:

Tap. Pooh, pooh! here, I know all about it.

Love. (Angrily.) And so do I, sir! and so do I!

Tap. Of course you do, and you've managed very well to keep it quiet so long. But you're a deep fellow, by Jove - you're a deep fellow!

Love. Now, mind! I restrain myself sufficiently to ask you once again, before I knock you down, by what right dare you tamper with the affections of Mrs. Lovetown? (8)

The essence of the quarrel, with each man utterly misunderstanding the statements of the other, is encapsulated by the experience of the actors, who are led into ignoring and interrupting one another's lines by the repeated cues. Indeed, Cox Jensen (Tapkins) observed that many of his repeated cues were at moments of agitation or conflict.

Reading Dickens's use of repeated cues to give his actors instructions regarding interruptions and escalation gives a sense of his professional expertise as a dramatist. The skit with which we opened this article is indeed a comic fiction: as the 'author' of the play, Dickens is neither absent, nor an unwelcome visitor. Not only did he regularly attend the rehearsals of his plays: his instructions were present in the cue-scripts themselves. 
It cannot be proven that actors followed these instructions. Indeed, it could be argued that actors would, at the first rehearsal, notice the repeated cues, and so wait for the repetition before speaking. This accords with what seems appropriate to a professional actor today; Murton noted that he was keen to 'iron out' interruptions in rehearsal, to ensure the clarity of the text, while Camilla Vernon (Mrs Lovetown) observed that she was alert to 'contextual cues', rather than relying on 'detached verbal cues'. However, this luxury may not have been available to a nineteenth-century actor. At the first performance at least, the actor, having rarely heard the others' lines in full, cannot help but respond to the cues, in dramaturgically effective ways. What became, for modern actors, a critical tool that could enhance sensitivity to particular aspects of performance, may have been, for nineteenth-century actors, a matter of pragmatic necessity - as well as creating, in the first performance, a sense of immediacy, cued by the practical knowledge of the playwright, which could then be incorporated into subsequent performances.

Dickens's mastery of this convention, and the extent to which he uses parts to signal character dynamics, was invisible to our audience members, who were unfamiliar with the practice. In their comments on the acting style, they focused instead on two more familiar conventions: a presentational acting style, and the use of asides. Here, Dickens masters a different kind of disappearing act: for the very fact that so little in Is She His Wife? is recognisably 'Dickensian' to a modern audience signals his success in deploying the form. Practice-led research thus highlights Dickens's success as a playwright, precisely because his plays are conventional rather than exceptional.

In our use of a presentational acting style, with actors facing outwards to the audience, we incorporated what Michael Booth refers to as: 
the 'point', a moment of intense physical or emotional action which was momentarily frozen in a powerful attitude or tableau - a kind of individualising of the group 'picture' that frequently concluded an act. ${ }^{20}$

These points were a key theatrical convention: Ellen Terry's Memoirs describe dressing-room advice from Edmund Kean to Edward Stirling, who played the second lead in The Iron Chest in 1829:

Kean: '. . . In the Library scene, sink gradually on your right knee, with your back to the audience. When I place my hand on your head to curse, mind you keep your eyes fixed on mine'. Stirling: 'Is that all, sir?' Kean: 'Yes - do whatever you like after that; it will be all the same to me.' 21

Is She His Wife? features a number of heightened moments which require this feature: for example, Dickens creates a group 'picture' in the final scene, demonstrating the harmonious reconciliation of the couples, as orchestrated by Tapkins. Another 'point' occurs when $\mathrm{Mr}$ Lovetown believes that Mr Limbury commiserates with him for Mrs Lovetown's betrayal, while Mr Limbury believes that Mr Lovetown speaks of his own seduction of Mrs Limbury:

Lim. . . Murderer of domestic happiness! Behold your victim!

Love. Alas! You speak but too truly! (Covering his face with his hands.) I am the victim!

Lim. I speak but too truly! He avows his own criminality! I shall throttle him, I know I shall! I feel it. (8)

Mr Lovetown's 'covering his face with his hands' is at once a gesture that expresses his mental turmoil, and enables him not to notice Mr Limbury's mounting distress, which is necessary in order for the misunderstanding to continue. Following Stirling's example, we choreographed this heightened moment, but, following Kean's advice to 'do whatever you like after that', we allowed the actors free choice in their movements, gestures, and characterisation (drawing on their own private line-learning processes, and on contemporary actors' tools where 
appropriate). The aiming at 'points' encouraged a heightened, gestural, presentational actor style, which worked particularly well in performance: audience members commented on how much they enjoyed 'the mannerisms', the 'melodramatic style of acting', 'the excellent historic staging', and (rather delightfully) Vernon's use of her 'pointy finger'.

Asides, as a key aspect of the dramaturgy of Is She His Wife, were another feature we spent some time on in rehearsal. The actors and director worked extensively on the modes and intentions of these asides, so that each actor developed an individual sense of their character's motivation in addressing the audience. As Mrs Lovetown, Vernon addressed the audience as a whole in her repeated bids for sympathy in asides and soliloquies. By contrast, Cox Jensen took the role first performed by the renowned low comic actor John Pritt Harley, which we may assume Dickens wrote with Harley's peculiar comic stylings in mind. Cox Jensen borrowed Harley's device of fixing a certain member of the audience with his eye, provoking (as in Harley’s original performances) both awkwardness and laughter. ${ }^{22}$

In the questionnaire responses, many audience members noted the significance of the asides to the success of the production. In response to the question 'What did you like about the production?', comments included: 'the asides are very effective'; 'humorous asides to the audience'; 'that they spoke their inner thoughts'; 'the asides to the audience [were] quite funny'; 'the access you get to all the characters' interior monologues through the aside is often hilarious'. The direct address here may not be comparable to the mastery of the narrative voice exhibited in, say, David Copperfield or Great Expectations, but it nonetheless demonstrates the extent to which Dickens's conventional success as a dramatist is facilitated, not by the authorial persona which was to ensure his fame as a novelist and his prominence as a cultural figure, but in his creation of convincing characters who are given the space to develop relationships with the audience. In his use of 'points', asides, and performance cues embedded in actors' parts, Dickens becomes an invisible puppeteer, successfully mastering the 
conventions of the form by stage-managing his own erasure. The author here does not 'call about' his piece, prompting irritation through his continued presence, but rather, in embedding his instructions within it, stages his own disappearance.

\section{'Oh who would sigh for a married life?' Making Music in Is She His Wife?}

In 1837, those formal conventions were legal as well as theatrical. As a minor theatre production before the Licensing Act of 1843, Is She His Wife? - billed as a burletta, an ostensibly mixed form - was required to feature music in addition to spoken drama. Moreover, the previous year Dickens had collaborated with the composer John Pyke Hullah on The Village Coquettes. If Dickens was indeed an inherently conventional theatrical writer, it is in precisely the 'mixed' aspects such as music that we should look, not for a proto-Wagnerian mastery of all forms, but for that collegiate attitude of self-effacement, collaboration, and authorial absence, to be most apparent. That this is indeed the case is not therefore remarkable; what is more noteworthy is that this disappearing act is so in evidence in a play that contains comparatively little music. No sheet music from the play appears to have been sold, and the later, published playtext omits its two complete songs entirely; we find these only in the manuscript copy submitted to the Licenser of Plays. In total, music (which, in common with much English theatre of the era, meant 'song') occurs at only four points in the play.

The second and third instances of music, which precede Tapkins's first and second appearances $(3 ; 4)$, demonstrate Dickens's ability to convey nuanced, layered meaning by conceding, not only narrative voice, but all ownership of the words sung. Tapkins, off-stage but in character, sings the second verse (slightly amended) and chorus of the Thomas Arne/Henry Fielding composition 'The Dusky Night Rides Down the Sky', more commonly known today as 'A-Hunting We Will Go', and then reprises the third line of this second verse 
- in essence voicing his own leitmotif - as he is seen 'crossing the garden' by Mrs Lovetown. (4)

The song offers a modern audience three insights. Firstly, the singer is identified with a rural huntsman (there are fitting undertones of sexuality in this) - though it is up to the audience to decide whether this is convincing self-fashioning. Secondly, by singing a hunting song in a major key, Tapkins marks himself out as happy, vigorous, carefree. Thirdly, the sentiment of the chosen verse wittily reflects the Lovetowns' marital argument, which it interrupts:

The wife around her husband throws,

Her arms, to make him stay;

'My dear, it rains, it hails, it blows,

And you cannot hunt to-day.'

Dickens's subtlety only emerges, however, when we appreciate the mentality of a middling audience of 1837, which would have been far more familiar with 'The Dusky Night', a mainstay of both street and drawing-room balladry, than an audience of today. Arne's 1777 tune, composed for a revival of The Beggar's Opera, is a setting of Fielding's lyric from 1734, but though venerable, the song remained in circulation. A comparison of Fielding's text with Dickens's reveals the latter's near invisible agency, for the original runs:

The wife around her husband throws

Her arms, and begs his stay;

'My dear, it rains, it hails, and snows, You will not hunt to-day?'

Dickens's alterations in the second and fourth lines transform a supplicatory wife into a domineering one, emphasising Mr Lovetown's sense of frustration. But it is from the verses not sung that Dickens gains his allusive riches. In its longer form 'The Dusky Night' contains 
a satirical twist: its third verse reveals that the huntsman has supplied a 'cartload' of foxes, in order to be 'secure' of finding his quarry - a quarry that proceeds to evade him, as his fellow hunters fall from their mounts, before turning 'hungry, homeward ... To feast away the night', the final chorus changing bathetically to 'a-drinking we will go'.

This caricature of the foolish amateur hunter is particularly apposite for Tapkins, 'Formerly of the India House, Leadenhall Street' (1), with his absurd rustic pretensions. ${ }^{23}$ The song therefore functions as an economical piece of dramatic irony, telling us more of Tapkins before he even enters than the Lovetowns do in their subsequent dialogue. This is a frame of reference that even the theatre historians in our second audience lacked; a reminder that in dealing with interpolated songs in nineteenth-century theatre, we are summoning unseen ghosts who speak in a lost language of musical allusion. It also underscores Dickens's ability to deploy song as contemporary prose writers deployed quotations within a text, marshalling the words (and, here, the notes) of others in the service of their own literary creations.

Tapkins is also given a second, original song. This unnamed entr'acte (entr'scène?) has no music, as a tune is neither specified nor implicit from the lyrics. The indication in the Licenser's copy that this song takes place between the two scenes, however, makes the music imperative: functionally, it must keep the audience diverted for the duration of the scene change. The lyrics have no conceivable bearing on Is She His Wife?, nor any literary merit, reading instead like a disposable piece of whimsy that Dickens already had up his sleeve for just such an eventuality. Though the direction 'Song - Felix Tapkins' is given, there is no link from his preceding monologue: this is a non-diegetic comic vehicle for Harley, highly malleable, placed primarily to fill in time.

From a practical perspective the challenge here was to supply music appropriate to the lyrics, the performer, and the circumstance. Those eight, reducible verses indicate a strophic form; the words fit a standard 6/8 ballad metre (each line containing four stresses, two to a bar): 
the obvious thing to do was to fit them to an existing comic tune. This was common practice, the interpolation of parodies of well-known popular songs a hallmark of the burletta. Ironically, the leading contemporary practitioner of this art was William Thomas Moncrieff, despised by Dickens for his premature adaptation of The Pickwick Papers. ${ }^{24}$ Moncrieff took many of his airs from versions of The Beggar's Opera. Given Dickens's similar literary influences at this period, and the evidence of 'The Dusky Night', it is reasonable to infer that he may have done the same - if the choice was even his, rather than Harley's, or a house composer. In selecting the tune ourselves, we may be echoing Dickens's original collaborators, who are less likely than us to have privileged the writer's suggestions when it came to choosing tunes for Harley, rather than for 'Tapkins'.

The melody of 'A Cobler there was, and he liv'd in a Stall' fits the metre perfectly; it was current at the time, and frequently appropriated for topical comic parodies. ${ }^{25}$ Its andante tempo, undemanding range, and simple, robust melodic shape are ideal for a performer such as Harley, who, Jim Davis notes, was famed for his buffo parlante approach to singing (a comic style closer to speech), whilst both heavy use of gesture and an irregular, conversational approach to timing seemed essential if the lyric was to succeed as light comedy. ${ }^{26}$ To reinforce its weak puns, and to evoke the low-comic stylings of Harley, Cox Jensen incorporated elements of mime to suit the lyrics, from looking through an imagined telescope, to sipping tea, to repeated simulations of flight. In an attempt to draw in the audience in Harley's manner, he picked out appropriate audience members for Venus and Mars, and shook hands with a likely looking Saturn in the front row. Most of these decisions were either developed in rehearsal or improvised, underlining the extent to which a song's effect - particularly when its lyrics are as thin as Dickens's are here - is constructed, not by the lyricist, but in the relationship between singer and audience in performance. In providing Harley, who revelled in these low 
comic interactions, with such a simple text, Dickens was demonstrating theatrical competence, exercising a light hand on the tiller.

This willingness to allow his collaborators agency extends to the only song whose lyrics Dickens appears to have written specifically for Is She His Wife?: the Lovetowns' duet, with which the play begins:

A married life,

Is not all joy;

But noise \& strife, Its charms alloy.

Tho' to please we do our best:

Misery'll our life infest -

Nought is right we e're can do,

But all is wrong $-\&$ all is rue!

Sometimes darling,

Oft times snarling

Now then pleasing

Then there teazing

Nought but care - and nought but strife

Oh, who would sigh for a married life. ${ }^{27}$

The structure is idiosyncratic, the rhyme scheme shifting, and the words themselves little more than doggerel. Clearly, their function was to complement an original, through-composed piece of music, likely to feature both repeats and call-and-response between the two singers. We needed to compose a setting with enough energy and melodic interest to warrant opening the performance, but also appropriate to both the words, and the two singers' roles within the play. Contemporary sheet music provided the starting point: the insistent simplicity of 'The Circulating Library', one of Harley's earlier hits; ${ }^{28}$ the chromatic minor sections of Dickens's own 'The Ivy Green', set by a Mrs Henry Dale in $1840,{ }^{29}$ and two duets: ' 'Tis Sweet to Gaze' from $1835,{ }^{30}$ and 'Strew, Strew with Roses' ${ }^{31}$ The latter proved the most instructive: written some time before by Charles Dibdin the Younger and William Reeve, it was 'Expressly Harmonized for Madame Vestris and Mr Braham' in 1840 by Henry Bishop, and thus seemed 
indicative of prevailing trends. Braham - himself a songwriter of note - was also the manager of the St James's, and likely to have been involved in the music performed on his stage. We adopted this song's key, C major, as a typical commercial strategy: songs were sold for domestic performance, and this was the easiest key for an amateur piano accompaniment. In the event, though our accompaniment featured similar use of arpeggiated chords to drive the tune forwards, a shadowing of the melody a third below at critical moments, and sustained major chords for the resolutions, it was performed on a replica of an 1830s guitar by Londonbased luthier Louis Panormo, a purely practical decision.

The aim was to write striking yet generically conventional music, an aim that further informed the song's modulations, vocal harmonies, and instrumental introduction. Within this framework, we attempted to achieve a certain degree of tone painting, so that the music echoed the drama. To this end, Mrs Lovetown leads and Mr Lovetown follows; his lines are initially emphatic and resolve on the tonic, whereas hers include trills, runs, and accidentals, conforming to contemporary gender stereotypes reinforced by Dickens's play. They harmonise when in agreement; a minor key chromatic passage mirrors despair; the vocal phrase for 'Then there teazing' does just that. Crucially, the coda attempts musically to align the Lovetowns with their attitudes in the ensuing dialogue, the forceful Mrs Lovetown resolving with a high note on the tonic, the sighing Mr Lovetown harmonising forlornly on the mediant. Though we strove, therefore, to reinforce rather than contest Dickens's writing, the process revealed the degree of authorial agency available to the composer of even a generically conservative theatrical song: in providing text for an original setting, Dickens was collaborating off as well as on stage, engaging in a cross-medial construction of theatrical meaning.

We are fairly certain that almost none of our precise musical intentions were consciously noted by our audience: an instructive exercise in both composing pastiche, and reflecting upon the changing functions and wholly subjective meanings of theatrical music. 
Indeed - though seven observers singled out the songs for positive comment, one specifying the duet - two expressed some discomfiture, one writing that 'Although the music was very good, it somehow was not what I was expecting', and another remarking that 'The songs were clearly a necessity of the time and felt a little out of place.' Asked to compare Is She His Wife? with other works they had seen, one referenced operetta, another The Marriage of Figaro; a third added that the songs lent it an eighteenth-century aspect.

There is a clear sense here that, though broadly receptive to music, a modern audience is used to preconceived categories, where 'musicals' and 'plays' occupy distinct conceptual spaces. There is also a sense, in both the discomfort and the breadth of reference points, that the audience struggled to reconcile this miscellany of music - an eighteenth-century hunting song, an out-of-character comic parody, a newly-composed duet - with their expectations of 'Dickensian' drama. Despite this confusion, they consistently reported enjoyment of the music. This reconciliation of what the audience took to be generic incoherence, with a willingness to be pleasurably entertained, is perhaps the fittest possible testament to the miscellaneous form of the burletta, the product, not of a single mind, but of many hands, voices, and bodies - a collaborative enterprise affording Dickens, Harley, and indeed us as composers and performers, the space to bring multiple specialisms to bear upon a single goal: that of pleasing the audience.

\section{'A Room Opening onto a Garden': Situating the Set}

We may also conceive of 'space' more literally, as the set itself is another means by which Dickens effects his disappearance. Despite growing trends for either spectacle or verisimilitude in other productions through the mid-nineteenth century, visual spectacle was not the reason for the obfuscation of Dickens's persona in Is She His Wife? Instead Dickens is effaced because of the set's generic quality. The stage directions given in the script indicate that the St James's 
production of Is She His Wife? used two-dimensional, stock scenery. The first scene is set in 'A Room opening onto a Garden' (3), and the second in Tapkins's garden, with 'A Conservatory on one side, a Summer House on the other.' (7) Unspecific and unelaborate, it is possible that the scenery could have been recycled from other productions, allowing Dickens's burletta to merge visually with the St James's existing catalogue. So although we chose to restage Is She His Wife? because it was written by Dickens, it is emblematic of wider genre and stage conventions, which make the play important historically, if not unique aesthetically.

Dickens was certainly conscious of how budgetary limitations for scenery might affect his success as a dramatist. When he first began to write The Village Coquettes in collaboration with Hullah, he persuaded Hullah to relocate their piece from Venice to England, reasoning, with

How little expense such a piece might be produced, and how very effective its situations might be made; while the Gondolier on the other hand would require a great many supernumeraries, and some rather costly scenery. ${ }^{32}$

Far from adhering to creative inspiration, Dickens thought through the material requirements that might prevent their operetta from appealing to Braham, the St James's manager.

Dickens's awareness of the St James's, and its company's, requirements and resources remains evident in the simple rural or interior settings of both The Strange Gentleman and Is She His Wife? This allowed Dickens to respond to the needs of the programme, as his productions could be staged quickly. The first mention of Is She His Wife? in Dickens's letters comes in January 1837, when he refers to "a little piece in one act called "Cross Purposes" written long before I was Boz. ${ }^{33}$ One month later on 27 February, the copied play script was received by the Lord Chamberlain's office; it was licensed for performance on 1 March, and performed for the first time five days later. ${ }^{34}$ 
In addition to the commercial considerations of a public performance, the simplicity of the set also suggests that Is She His Wife? could be performed domestically. Indeed, the fact that we were able to stage the production on two separate sites, with different spatial dimensions, further indicates its transposability between public and private theatricals. Given Dickens's business acumen in his dealings with the St James's, it is likely that this was a consideration for him when writing the play: not only was Dickens a keen amateur actor who staged domestic read-throughs of his own plays, but he was also conscious of the extra money to be made by publishing printed copies of the script. ${ }^{35}$

It has occurred to me recently, that if it should make a very great hit, and were published during the run, it would be very likely to have a considerable sale. ${ }^{36}$

A generic set thereby complements the stock character and plot devices to support Dickens's ambition to appeal to a mass audience.

In order to test the effect of a historically informed production style, we designed and built a set based on the directions given in the play script, and on research into contemporary stage techniques and fashion. We painted a backcloth, built stage flats, and hired props and costumes that were period appropriate (see Figure 1). We used footlights and wing lights, and kept the house lights up. All of these features were common on the nineteenth-century stage albeit on a grander scale.

\section{Figure 1: Plan of the set design for Is She His Wife?}

In spite of the scenery's simplicity and apparent unobtrusiveness, we quickly realised in our rehearsals that the set was essential to the comedy. Spaces for characters to hide and peep ('I am sure she is behind the screen, I saw her peeping') enable the confusion of 
circumstances that drive the farce. (6) The physical limitations of our set also intensified the comedy. Actors noted that the set was 'tricky': 'we were constantly pushing at the scale of the set, aware of its restrictions but loth to obey them ... the space became highly constrictive and definitely inhibiting to expression'. Yet, as Vernon commented:

The set is always the physical boundary for the actor . . . The trick is learning to use those boundaries to your advantage - particularly in a comedy. If your giant skirt knocks over a tea cup, or a door even, it still works.

The physical experiences of the actors, negotiating hiding behind flats in constrictive costumes, mapped onto and intensified the physical comedy of the play itself. Practice-led research thus allowed us to see the set as a tangible element of the storytelling. Though generic, it provides visual and physical cues external to the written scene, which the actors use collaboratively with the dialogue to emphasise the comic mood. Dickens must ultimately relinquish authorial control to the actors' interpretation and interaction with the material properties, yet by writing instances of hiding and peeping into the script, he indicates the playful way he wants the scenery to be used. Dickens disappears behind his scenes, influencing the stylistic decisions of his collaborators.

Ephemerality characterises performance, but it also typifies the material elements of theatre. Not only was it necessary for us to dispose of our set afterwards, but the physical setting also highlighted the distance between the cultural standards of our modern audiences and those of the nineteenth century, even while facilitating their sensory engagement with the text. Certain elements of the design discomforted members of our audiences, who remarked that they had not liked the shared lighting between the stage and the 'auditorium', created by leaving the house lights on. One commented that the '[b]right lighting [was] strange' even though they 'understood reasons for it'. 
This unfamiliar lighting was essential to the play's dramaturgy, as it facilitated the actors' direct address to the audience, even if the audience was not conscious of this need when looking from the other direction. As discussed above, the delivery of asides was one of the most successful elements of the performance: this depended upon the visibility of the audience to the actors. Murton commented:

Shared lighting can be both helpful and tricky. It helped due to asides and engaging with the audience.

For Cox Jensen, the shared lighting conditions enabled his delivery of asides to individual audience members:

I attempted to move around the room in my choices, mixing ages and genders, and especially to pull in more remote audience members.

Vernon likewise noted that she was able to address particular audience members:

The nature of the asides were such that it felt like the more personal approach - like a shared secret between two friends.

Feedback indicates that the historically informed scenery did not contribute explicitly to most of the audience's enjoyment of the play, yet the actors' experiences show that both the set and the shared lighting were necessary for the dramatic action. The former facilitated much of the physical comedy, to which the audience audibly responded, and the latter made possible a key, popular feature of the play's dramaturgy. Constructing and using the set thereby illuminated the central tension of practice-led stagings of nineteenth-century drama: the aspects that were most alienating to our audiences were also the most integral to the success of the production. 
The sense of alienation occasioned by the material properties also highlighted the distance between Dickens's modern cultural status, and his unobtrusiveness as a dramatist. Some of the ways in which the audience experience of the play's material conditions obscured Dickens echo that of nineteenth-century playgoers. Unlike private novel reading, which might induce feelings of intimacy with the author's works, the audience watched the play as part of a group. The reactions of other audience members thereby acted as another mediating factor between playwright and playgoer, influencing individual experiences - as is true of any theatrical event. Reactions to Is She His Wife? were also affected by other material and cultural features peculiar to a modern context, and to our practice-led performances in particular: the specific cultural spaces in which these events took place, King's College London and the Charles Dickens Museum, helped to create a palpable sense of disjunction between Dickens's status as a heritage figure, and Dickens as an invisible dramatist.

As heritage and educational institutions, each of these spaces implies certain cultural narratives, as well as being bound up in individual institutional agendas. Watching a modern staging of Is She His Wife? therefore requires a kind of double-vision. The set acted as a visual invitation to the audience to suspend their disbelief for the duration, but its materiality simultaneously highlighted its constructed nature. Because of limitations of budget, space, and skill, audiences saw the set and the space around it at the same time. The flats were only six feet tall, and so did not reach the ceiling in either performance space. Moreover, wear-and-tear caused by transportation meant that by the second performance one of the flats began to lean forwards ominously, causing further problems for our taller cast members, who already had to duck to ensure they remained hidden while offstage. The audience's experience of the 'Room Opening onto a Garden' was thereby mediated by the colours and fittings of the surrounding spaces, which were enhanced by the shared lighting. With reference to Jay David Bolter and Richard Grusin's concept of remediation - characterised by the 'oscillation' between 
immediacy (the suspension of disbelief), and hypermediacy (an awareness of media) - this overlay of real and imagined spaces meant that these audience experiences similarly oscillated between enjoyment of the farce, and varying degrees of consciousness of other spatial narratives. ${ }^{37}$ Institutional and cultural narratives thus inflected individual expectations or experiences.

Audience consciousness of spatial narratives external to the action was especially heightened during the second performance at the Charles Dickens Museum. Even though we did not use the museum itself as a set, the location was testament to Dickens's modern cultural legacy as a heritage figure. Located in the house where he was living when Is She His Wife? was first performed at the St James's, the museum is a site of significant biographical interest. Negotiating multiple binaries in our practice - between reading and performance, nineteenthcentury theatrical cultures and modern reconstructions - doubleness characterises staging $I S$ She His Wife? still further, as it is impossible to discount Dickens's cultural importance when responding to a modern production. Staging the play in the Charles Dickens Museum thus carries certain connotations about Dickens's cultural significance, as well as raising questions about the place of literature in the heritage industry more widely.

Modern audiences were aware of a contradiction between Dickens's present canonicity and fame, and the obscuring of his writerly persona in the play's generic material and imaginative qualities. Several people used the questionnaires to comment that they found its conventionality unexpected, by contrast with the originality they associated with Dickens. In its brevity, its small cast, and its limited setting, the play lacks the mobility and populousness associated with Dickens as the Great Conductor of his later fictional and editorial endeavours. Some audience members ascribed this 'unDickensian' conventionality to his position in 1837 as a young writer learning his craft, while one respondent suggested that Dickens's style could 
not be recognised because of the play's rural setting, indicating that Dickens's fame as a 'London' novelist influenced the play's reception.

While Dickens's proficiency as a dramatist is highlighted by his unobtrusiveness and collegiality, the complication presented by his dramatic writing is that, for the audience, he did not disappear. In fact, the doubleness faced by a modern audience reflects a disjunction also present in 1837. Although Dickens had not hit the giddiest heights of his fame when he became involved with the St James's, by the first night of The Village Coquettes he was able to use the space of the playhouse to act the part of celebrity dramatist, appearing on stage after the curtain to receive the audience's applause. ${ }^{38}$ Yet staging our production in institutions that reinforce Dickens's primacy (whether by affirming his significance to British heritage, or through teaching his works as part of a literary canon) paradoxically enabled us to distance our practiceled research from Dickens's modern cultural meanings. Because the set was the element of our production that the audiences found most alienating, the distance between the material and embodied realisation of Dickens's dramatic writing and the way in which he is now commonly perceived was made more evident: it became possible to conceive of both these things simultaneously due to the particular performance spaces. The ways in which the actors' performances and the music interacted with the material properties of our constructed set meant that we were able to see Dickens at work as a collaborator, or as an entrepreneurial pragmatist whose writing was influenced by external factors, alongside literal and institutional signifiers of his status as exceptional 'genius'. The particular spaces and material conditions of our practice-led research thus enabled us to assess the performability and success of Is She His Wife? precisely because of the different ways in which they constructed Dickens. 


\section{Conclusion}

Generic, collaborative, and pragmatic, Dickens's dramatic writing sheds light on wider generic conventions and functional networks operating within nineteenth-century theatre. Although Dickens is not an important dramatist, his drama is important, for the insights it affords into nineteenth-century theatrical cultures, and for the methodological experiments it enables. Ironically, Dickens's generic plays were preserved, archived, and digitised because they were written by the Inimitable Boz. Similarly, our practice-led research project was inspired by the writer, rather than the qualities of Is She His Wife?, and attracted the necessary funding from numerous bodies because of Dickens's appeal to both academic and public audiences. ${ }^{39}$ It is because of his canonical status, not in spite of it, that our practice-led research was able to explore marginalised genres, texts, and conventions. In looking at Dickens, our methodology allowed us to look past him, because it demanded that otherwise overlooked performance elements achieve embodied expression. Often disregarded because of their conventionality, generic forms of music, performance, and staging were the bread and butter of the nineteenth-century stage. Plays like Is She His Wife? pointedly demonstrate the intertheatricality of dramatic cultures because they present a richly allusive matrix of influences: mining existing conventions and material properties so as to be produced quickly to answer audience demand. Thus Dickens's success as a dramatist relies on his disappearance, because his works can only exist as part of a larger conversation between theatre-makers and their audiences. What we learn about Dickens from staging Is She His Wife?, we learn about nineteenth-century drama more generally. Dickens is a commercially successful dramatist, precisely because he does not try to be singular. 


\section{Appendix: Audience Response Questionnaire}

A questionnaire comprised of the following questions was distributed to audience members at both performances of Is She His Wife? The first (17 Sep 2015) was held at King's College London, and was a free event open to the public. The event was advertised online through appropriate mailing lists and websites (e.g. the Dickens Our Mutual Friend Online Reading Project, which attracted involvement from academics and interested members of the public). The maximum capacity for this event was sixty. The second (18 Sep 2015) was held at the Charles Dickens Museum, and followed the academic symposium 'Dickens and Drama'. The maximum capacity for this event was twenty-five. Forty-eight questionnaires were returned overall.

1. What did you like about the play?

2. What did you dislike about the play?

3. Were you aware that Dickens had written plays as well as novels? If so, what was your impression of him as a dramatist?

4. Are there any qualities of the play that you would call 'Dickensian'? (Please give details about which parts of the play, and why you think they are 'Dickensian', or not.)

5. Have any of your preconceptions about Dickens changed because of this performance? (Please give details.)

6. Did this performance remind you of any other dramas that you have seen?

\footnotetext{
${ }^{1}$ Charles Dickens, 'Authors and Actors; or, Engaging a Company', Bentley’s Miscellany, 1 (January 1837), 132-8, p. 132.

2 See Emma Curry, 'Doing the Novel in Different Voices: Reflections on a Dickensian Twitter Experiment', 19: Interdisciplinary Studies in the Long Nineteenth Century, 21 (2015), first published online 10 Dec 2015, doi: 10.16995/ntn.736.

${ }^{3}$ Charles Dickens, The Letters of Charles Dickens, The Pilgrim Edition, Volume One 1820-1839, ed. Madeline House and Graham Storey (Oxford: Clarendon Press, 1965), pp. 177-8.
} 
${ }^{4}$ Charles Dickens, Is She His Wife? or, Something Singular. A Comic Burletta, in One Act. No. 470. Dicks' Standard Plays (London: John Dicks [undated]), p. 5. All subsequent quotations are taken from this edition. Page numbers will follow in brackets.

${ }^{5}$ Richard Pearson, Victorian Writers and the Stage: The Plays of Dickens, Browning, Collins and Tennyson (Basingstoke: Palgrave Macmillan, 2015), p. 42.

${ }^{6}$ H. Philip Bolton, Dickens Dramatized (London: Mansell Publishing Limited, 1987), p. 109.

${ }^{7}$ Is She His Wife? dir. Emma Whipday, <youtube.com/watch?v=pMYa2ygZP1Q>, first published online 24 Nov 2015.

${ }^{8}$ Baz Kershaw with Lee Miller/Joanne 'Bob' Whalley and Rosemary Lee/Niki Pollard, 'Practice as Research: Transdisciplinary Innovation in Action', in Baz Kershaw and Helen Nicholson (eds), Research Methods in Theatre and Performance (Edinburgh: Edinburgh University Press, 2011), pp. 63-85, pp. 63-4.

${ }_{9}^{9}$ Marvin Carlson, 'Theorizing the Performative Event', in Julia Swindells and David Taylor (eds), The Oxford Handbook of The Georgian Theatre, 1737-1832 (Oxford: Oxford University Press, 2014), pp. 53-69, p.67.

${ }^{10}$ Jacky Bratton, New Readings in Theatre History (Cambridge: Cambridge University Press, 2003), pp. 37-8.

${ }^{11}$ Stephen Purcell, Shakespeare and Audience in Practice (Basingstoke: Palgrave Macmillan, 2013), p. 17.

${ }^{12}$ Diana Taylor, The Archive and the Repertoire: Performing Cultural Memory in the Americas (Durham, NC: Duke University Press, 2003), p. 19, original emphasis.

${ }^{13}$ Jerome K. Jerome, On the Stage and Off (New York: Henry Holt and Company, 1891), p. 40. Thanks are due to Philip Bird for drawing our attention to Jerome's observation.

${ }^{14}$ Bratton, New Readings, pp. 22-3.

15 Jerome, On the Stage, p. 40.

${ }^{16}$ Simon Palfrey and Tiffany Stern, Shakespeare in Parts (2nd edn, Oxford: Oxford University Press, 2010), p. 2.

${ }^{17}$ See Jakub Boguszak, ‘An Actor's Jonson: Parts and Instructions’, DPhil thesis, University of Oxford, 2016.

${ }^{18}$ See Emma Whipday and Freyja Cox Jensen, 'Original Practices and Historical Imagination: Staging A

Tragedie Called Merrie', Shakespeare Bulletin [in peer review].

${ }^{19}$ See Palfrey and Stern, Shakespeare, pp. 157-64.

${ }^{20}$ Michael R. Booth, Theatre in the Victorian Age (Cambridge: Cambridge University Press, 1991), p. 125.

${ }^{21}$ Ellen Terry, Ellen Terry's Memoirs, ed. Edith Craig and Christopher St. John (London: Victor Gollancz, 1933), p. 13, cited in George Taylor, Players and Performances in the Victorian Theatre (Manchester:

Manchester University Press, 1989), p. 2.

22 Jim Davis, Keynote Address, 'Dickens and Drama', Charles Dickens Museum, 18 Sep 2015.

${ }^{23}$ This was a common theme of songs of the day: see e.g. 'Going Out A-Shooting', British Library Mus H.1652.m(32).

${ }^{24}$ See Jacky Bratton, 'William Thomas Moncrieff: Master or Monster of Nineteenth-Century Adaptation?', Nineteenth Century Theatre and Film (tbc).

${ }^{25}$ Oskar Cox Jensen, Napoleon and British Song, 1797-1822 (Basingstoke: Palgrave Macmillan, 2015), p. 46.

${ }^{26}$ Davis, Keynote.

${ }^{27}$ British Library, Lord Chamberlain's Plays Collection, Add MS 42940. [Charles Dickens], 'Is She His Wife? or, Something Singular!', in Plays from the Lord Chamberlain's Office, Vol. LXXVI, Feb.-Mar. 1837, fos 62548 , fol. 627.

${ }^{28}$ British Library Mus G.424.pp (27).

${ }^{29}$ British Library Mus H.1667 (5).

${ }^{30}$ British Library Mus R.M.13.f.17.

${ }^{31}$ British Library Mus H.1653.f (22).

${ }^{32}$ Dickens, Letters, p. 113.

${ }^{33}$ Ibid., p. 226.

34 'Is She His Wife?' fol. 625.

${ }^{35}$ Dickens, Letters, p. 155.

${ }^{36}$ Ibid., p. 172.

37 Jay David Bolter and Richard Grusin, Remediation: Understanding New Media (Cambridge, MA, and London: MIT Press, 2000), p. 19.

${ }^{38}$ Michael Slater, Charles Dickens (New Haven and London: Yale University Press, 2011 [2009]), p. 88.

${ }^{39}$ Our thanks are due to King's College London and the British Association for Victorian Studies for their support. 